\title{
Leadership Style, Organizational Commitment and Job Satisfaction: A Case Study on High School Principals in Tehran, Iran
}

\author{
Reza Omidifar \\ Oromiye University, Oromiye, Iran
}

\begin{abstract}
Teachers' job satisfaction and commitment depends upon the leadership style of high schools principals. This study clarifies the relationship between principals' leadership style, organizational commitment and job satisfaction. A quantitative questionnaire using Likert-type scales was administered to 357 high school teachers and principals in Tehran, Iran. The study samples were selected through stratified sampling technique. The data was tested for reliability and results presented based on the study objectives. Pearson correlation coefficient was used to explain teacher job satisfaction and commitment by leadership style. The results revealed positive and significant relationships between leadership style, organizational commitment and job satisfaction. This study also clarifies the relations of job satisfaction and commitment, and highlights the crucial role of leadership style in teachers' job satisfaction and commitment. Hence, the school principals should select the best leadership style according to the organizational culture and employees' capacity. Implications of the study are discussed in relation to managers and principals, as well as to policy makers at the educational level.
\end{abstract}

Keywords: Organizational commitment, job satisfaction, leadership style, management

\section{Introduction}

The purpose of this study was to investigate the relationship between manager's leadership style, organizational commitment and job satisfaction of high school teachers in Tehran, Iran. Job satisfaction and commitment of the teachers are the important elements to increase the productivity of a school. The benefits of organizational commitment have been well documented in the extant management literature. Principals' leadership style imposes great influence on the working attitudes, and performance of employees.

In particular, supportive leadership can give rise to employees' reaction, generating significant and positive relationship with employees' job satisfaction (Samuel 2011). Committed employees are less likely to develop patterns of tardiness or to be chronically absent from work (Angle \& Perry, 1981; Bateman \& Strasser, 1984; Porter et al., 1974, Davenport, 2010). Employees that are committed are also less likely to leave the organization to explore other opportunities (Yukl, 2003, Allen \& Meyer, 1996).

Despite the large number of studies on organizational commitment and job satisfaction (Price \& Mueller, 1981; Allen \& Meyer, 1996), the influence of leadership style on organizational commitment and job satisfaction has received little attention. Hence, this study attempts to establish the relationship between leadership style organizational commitment job satisfaction high school teachers in Tehran, Iran

\section{Literature Review}

\section{Leadership style}

An important issue to address in this literature review is leadership because so much job satisfaction depends on leadership style (Aref, Montgomery \& Ma'rof). Leadership is defined as the ability to influence a group towards the achievement of goals (Robbins, 1993). It is widely recognized as a critical factor in the success or failure of an organization (Hasbullah, 2008). Leadership enables an organization to translate its potential for good performance into productivity (Samuel, 2005). Fiedler (1967) believed that leadership is a kind of relationship to apply power and influence to make people work together and accomplish common goals (Wu et al., 2006). Leadership is a social influence process in which the leader seeks the voluntary participation of subordinates in an effort to reach organization goals (Omolayo, 2000).

Daft (2005) defined leadership as an influence relationship among leaders and followers who intend real changes and outcomes that reflect their shared purposes. Previous research has linked supportive leadership style to delivery of job satisfaction. Singh 
(2000) found that frontline employees felt that supervisory support enhanced their performance levels. Brown and Peterson (1993) found that contact employees who believed their manager showed concern for them exert more effort in the workplace.

Leaders should understand that the issue of employees' organizational commitment is a crucial element to be addressed to (Tushman \& O'Reilly; Nadler, 1997).

The existing leadership and management research suggests that the leadership style of principals can lead to higher measures of organizational commitment in their direct reports. Bass, (1985); Hersey \& Blanchard, (1977); and Stogdill, (1963) demonstrated positive relationships between numerous leadership styles and employee attitudes, motivation and performance; all of which can affect to organizational commitment levels.

\section{Organizational Commitment}

Organizational commitment is influenced by the job environment created by the employee's supervisor. This organizational environment, together with the employee's ability and motivation, will largely determine eventual performance (Cummings \& Schwabs, 1973). Organizational commitment has also been shown to positively affect motivation, organizational citizenship, and job performance (Meyer et al., 2002).

Organizational commitment is regarded as a mental contract connecting the individual's identification and attribution with the organization and performing his duty (Wallace, 1995). Organizational commitment is able to facilitate voluntary cooperation within an organization (Wu et al., 2006).

Despite the sense that organizations are enacting strategies that imply less commitment toward employees, Scott-Ladd, Travaglione, and Marshall (2006) suggest that organizational commitment continues to be a powerful attitudinal response in employees. A good portion of the research on organizational commitment has focused on the possible antecedents of organizational commitment. However, the benefits of organizational commitment have well been documented: satisfaction, performance, lower turnover and lower absenteeism.

Organizational commitment means the degree of one's identification with, and participation in, a certain organization. It includes three characteristics: (a) one believes in, and accepts, organizational goals and value (value commitment), (b) one is willing to make an effort (effort commitment), and (c) one has a strong desire to remain a member of the organization (retention commitment) (Porter, Steer, Mowday \& Boulian, 1974, Wu et al., 2006).
Morris and Sherman (1981) indicated that organizational commitment is able to effectively predict the employee's performance and turnover. Meyer, Paunonen, Gellatly, Goffin, \& Jackson (1989) also found that organizational commitment was a proper indicator of work performance. It is important for managers and leaders to pay more attention to the employee's organizational commitment (Wu et al., 2006).

\section{Job Satisfaction}

Job satisfaction has been described as the most important predictor for employees' intention to remain employed (Cowin, 2002. Job satisfaction is a result of employee's perception of how well their job provides those things that are viewed as important. According to (Mitchell \& Lasan, 1987), Job satisfaction is simply defined as employees' feelings about different dimensions of their job; it is the degree of their pleasure in their job (Spector,1997). Job satisfaction is the attitude that an employee has towards his or her job (Robbins, 2003). Job satisfaction is an affective reaction to a job that results from a person's comparison of outcomes with those that are desired, anticipated or deserved (Oshagbemi, 1999).

Job satisfaction can be considered from a global perspective, such as the feelings and emotions perceived by the individual employee based on work experiences (Price, 2001 \& Spector, 1997). It can also be explored through a facet approach, studying employee attitudes towards various aspects (facets) of their jobs.

\section{Research objectives}

i) To examine the relationship between leadership style and organizational commitment

ii) To examine the relationship between Leadership style and job satisfaction

iii) To establish the relationship between organizational commitment and job satisfaction.

\section{Methodology}

A quantitative questionnaire using Likert-type scales was used to obtain measures of leadership style, job satisfaction and organizational commitment. The questionnaire was self administered for clarity purposes as it sought to find out respondents' opinions. A pilot study based on 30 returned questionnaires showed that respondents were clear about the content of the questions and instructions. The results of the pilot study revealed that 
Cronbach's acoefficients for the leadership style, organizational commitment and job satisfaction were 0.93 and $0.91,0.89$ respectively, which showed a high degree of reliability.

The study samples were selected through stratified sampling technique. Pearson correlation coefficient was used to explain teacher job satisfaction and commitment by principals' leadership style. The sample consisted of the high school teachers and principals drawn from four districts of Tehran including the district of $3,11,5$ and 14.

A total of 357 questionnaires were gathered. The questions were generated through a literature review from House (1971); Fleishman, (1957); Stogdill, (1963), Faragher, Cass and Cooper, (2003).

Secondary data was obtained from existing literature in previous research paper findings, journal articles, text books, reports and conference proceedings.

\section{Variables and their Measurement}

Leadership style

Leadership style was measured on a 5-point likert scale $(1=$ strongly disagree, $5=$ strongly agree) using 12 -item of leadership style consisting of attributes like participative, supportive and directive (House 1971; Fleishman, 1957; Stogdill, 1963). It was based on statements such as "helps teachers to make working on their tasks more pleasant".

Organizational commitment
Organizational commitment was measured by the items of Meyer \& Allen's (1997). The respondents were asked to indicate their opinion on a 5-point scale $(1=$ strongly disagree, $5=$ strongly agree). For example "I would be happy to spend the rest of my career with this school".

\section{Job satisfaction}

Job satisfaction was measured by items adapted by Faragher, Cass and Cooper, (2003). It was based on a 5 -point likert scale $(1=$ Very dissatisfied, $5=$ Very satisfied).

\section{Findings}

The results presented were guided by the research objectives which were:

(ii.) To investigate the relationship between leadership style and organizational commitment.

(iii.) To establish the relationship between leadership style and job satisfaction.

(iv.) To examine the relationship between Organizational commitment and job satisfaction.

The objectives of the study were based on the relationships between principals' leadership style, organizational commitment, job satisfaction in high school teachers. In order to achieve this, the Pearson correlation coefficient was computed given the interval nature of the data and the need to test the direction and strength of relationships that exist among the study variables. Table 1 presents the correlation analysis results.

Table 1. Pearson correlations.

\begin{tabular}{lllll}
\hline & & $\begin{array}{l}\text { Leadership } \\
\text { Style }\end{array}$ & $\begin{array}{l}\text { Organizational } \\
\text { Commitment }\end{array}$ & $\begin{array}{l}\text { Job } \\
\text { Satisfaction }\end{array}$ \\
\hline Leadership Style & Pearson Correlation & 1.000 & & \\
& Sig. (2-tailed) & & & \\
& $\mathrm{N}$ & 357 & & \\
Organizational Commitment & Pearson Correlation & $318^{* *}$ & 1.000 & \\
& Sig. (2-tailed) & .000 & & 1.000 \\
& $\mathrm{~N}$ & 357 & 357 & 357 \\
& Pearson Correlation & $278^{* *}$ & $331^{* *}$ & .000 \\
\hline
\end{tabular}

** Correlation is significant at the 0.01 level (2-tailed).

\section{The relationship between leadership style and organizational commitment}

A positive and significant relationship was observed to exist between leadership style and organizational commitment $(\mathrm{r}=.318 * *, \mathrm{p}<.01)$. This means that when the principals listen to teachers, encourage employee participation, team work, freedom in doing school activities, organizational commitment by teachers is enhanced. This commitment is 
exemplified in the teachers' desire to spend most of their career in the school, believe in the mission and values of the institution. These results are in line with the previous studies in general and in specific with Drago et al, 1992; Samad, 2007; Opkara, 2004; Warsi,Fatima \& Sahibzada;2009.

\section{The relationship between leadership style and job satisfaction}

The correlations indicate a positive relationship between leadership style and job satisfaction ( $\mathrm{r}=$ $\left..278^{* *}, \quad \mathrm{p}<.01\right)$. This observation signifies that supportive of principals tend to lead to increased employee job satisfaction. Job satisfaction may be seen when employees devote all their time and skills towards attaining school goals.

\section{The relationship between organizational commitment and job satisfaction}

The results indicated a positive relationship between organizational commitment and job satisfaction $(\mathrm{r}=$ $.331 * *, \mathrm{p}<.01)$. The results imply that organizational commitment lead to job satisfaction. This will lead to improvement in the willingness of the employees to help students, being never busy to respond to students requests and consistently being courteous with students.

\section{Conclusion and Discussion}

This study investigated the relationship between principals' leadership style, organizational commitment and job satisfaction of high school teachers in Tehran. The study found that there is a significant relationship between leadership style, organizational commitment and job satisfaction. Hence, schools should create environments where teachers can optimize their potential and add value to the educational aims. In these way high schools principals play a very important role in creating and maintaining these environments.

\section{References}

Allen, N.J. \& Meyer, J.P. (1996). Affective, continuance and normative to the organisation: An examination of the construct validity. Journal of Vocational Behaviour, 49, 252276.

Angle, H. \& Perry, J. (1981). An empirical assessment of organizational commitment and organization effectiveness. Administrative Science Quarterly, 26, 1-14.

Aref, F., Montgomery, C., Ma'rof R (2013). The Importance of Leaders' Characteristics in Community Capacity Building for Tourism Development, International Journal of Community Development, 1(2). 58-62. DOI: 10.11634/233028791301429
Bateman, T. \& Strasser. (1984). A longitudinal analysis of the antecedents of organizational commitment. Academy of Management Journal, 27, 95.

Bass, B. M. (1990). Handbook of leadership: A survey of theory and research. New York, Free Press.

Brown, S.P., \& Peterson, R.A. (1993). Antecedents and consequences of salesperson job satisfaction: Meta-Analysis and Assessment of Causal Effects. Journal of Marketing Research, 30, 63-77.

Cowin, L. (2002). The effects of nurses job satisfaction on retention. Journal of Nursing Administration, 32(5),283-291.

Cummings, L.L. \& Schwab, D. P. (1973). Performance in Organizations: Determinants and Appraisal. Glenview: Scott, Foresman and Company.

Davenport, John (2010). Leadership style and organizational commitment: The moderating effect of locus of control, proceedings of ASBBS, 17(1). ASBBS Annual Conference: Las Vegas, Feb 2010

Daft, R. (2005). The leadership experience. Toronto: Southwestern.

Drago, R., Estrin, S., Wooden, M. (1992). 'Pay for performance incentives and work attitudes', Australian Journal of Management, 17(2).

Faragher, E. B, Cass, M., \& Cooper, C.L. (2003).The relationship between job satisfaction and health: a meta-analysis, Journal of Occupational Environmental Medecine, 62,105-112.

Fiedler, F. E. (1967). A theory of leadership effectiveness. New York: McGraw-Hill.

Fleishman, E. A. (1953). The description of supervisory behavior. Journal of Applied Psychology, 37(1), 1-6.

Hasbullah, N. B. (2008). The relationship between leadership behaviour and organizational commitment: A study in the cooperative societies in Peninsular Malaysia, Unpublished MBA dissertation Submitted to University of Malaya

Hersey, P., \& Blanchard, K. H. (1988). Management of organizational behavior: Utilizing human resources (5th ed.). Englewood Cliffs, New Jersey, USA: Prentice Hall.

House, R. J. (1971). A Path-goal theory of leader effectiveness. Administrative Science Quarterly, 321-338.

Meyer, J. P., Paunonen, S. V., Gellatly, I. R., Goffin, R. D., \& Jackson, D. N. (1989). Organizational commitment and job performance: It's the nature of the commitment that the counts. Journal of Applied Psychology, 74, 152-156.

Mitchell, T.R.,\& Lason, J.R. (1987). People in organizations: An introduction to organizational behavior(3rd ed.). New York: McGraw-Hill.

Mowday, R., Porter, L. \& Dubin, R. (1974) Unit performance, situational factors and employee attitudes in spatially separate work units. Organizational Behaviors and Human Performance, 12: 231-248.

Morris, J. H., \& Sherman, J. D. (1981). Generalizability of an organizational commitment model. Academy of Management Journal, 24, 512-526.

Okpara, J. O. (2004). Job Satisfaction and Organizational Commitment: Are there differences between American and Nigerian Managers Employed in the US MNCs in Nigeria? Academy of Business \& Administrative Sciences, Briarcliffe College, Switzerland.

Omolayo, B.O. (2000). Psychology of human being at work. AdoEkiti: Crown House Publishers, 101-103.

Oshagbemi, T. (1999). Overall job satisfaction: How good are single versus multiple-item measures? Journal of Managerial Psychology, 14,388-403.

Porter, W., Steers, R.., Mowday, T. \& Boulian, V. (1974), Organisational commitment, job satisfaction and turnover among psychiatric technicians, Journal of Applied Psychology, 59 (5) 603-9.

Price, J. L., \& Mueller, C. W. (1986). Handbook of organization measurement. Marshfield, Massachusetts, USA: Pitman.

Price, J.L. (2001). Reflections on the determinants of voluntary turnover. International Journal of Manpower,22(7),600-624. 
Robbins, P. (1993). Organizational behavior. Prentice-Hall, Inc., 366-392.

Robbins, P. (2003). Organisational behaviour: Global and South African perspective. Englewood Cliffs: Prentice Hall.

Samad, S. (2007). Assessing the Effects of Job Satisfaction and Psychological Contract on Organizational Commitment among Employees in Malaysian SMEs. The 4th SMEs IN A Global Economy Conference.

Samuel, G. (2005). The relationship between leadership and internal customer satisfaction within a motor manufacturing company in Gauteng, Unpublished MBA dissertation Submitted to Rhodes University.

Samuel O. J. (2011). Leadership Behaviour, Organisational Commitment, Job Satisfaction and Service Quality in Commercial Banks in Uganda A Case of Kampala District, Master Thesis, Makerere University.

Scott-Ladd, A. Travaglione, \& V. Marshall. (2006). Causal inferences between participation in decision making, task, attributes, work effort, rewards, job satisfaction and commitment. Leadership \& Organization Development Journal 27 (5): 399-414.11.

Shader, K., Broome, E., Broome, D., West, E. \& Nash, M. (2001). Factors influencing satisfaction and anticipated turnover for nurses in an academic medical centre. Journal of Nursing Administration 31, 210-216.

Singh, J. (2000), "Performance productivity and quality of frontline employees in service organisations", Journal of Marketing, 64:15-34.

Spector, P. (1997). Job satisfaction: Application, assessment, cause and consequences, London, Sage Publications.
Stogdill, R. M. (1963). Manual for the leadership behavior description questionnaire-form X11. Columbus, Ohio, USA: Ohio State University.

Tannenbaum, R., Weschler, I. R., \& Massarik, F. (1964). Leadership and organization. New York, USA: McgrawHill.

Tain-Fungwu, Mei-Hui Tsai1, Yeh-Hsun Fey, \& Robert T. Y.Wu (2006). A study of the relationship between manager's leadership style and organizational commitment in Taiwan's international tourist hotels. Asian Journal of Management and Humanity Sciences,1(3).434-452.

Tushman, M. L., O־Reilly; C. A \& Nadler, N. A. (1997). Winning through innovations. Boston, MA: Harvard Business School Press.

Warsi, S., Fatima, N., \& Sahibzada, S. A. (2009). Study on relationship between organizational commitment and its determinants among private sector employees of Pakistan, International Review of business Research papers, 5(3), 399410.

Wallace, J. E. (1995). Organizational and professional commitment in professional and nonprofessional organizations. Administrative Science Quarterly, 40, 228255.

Wu et al. (2006). A Study of the Relationship between Manager's Leadership Style and Organizational Commitment in Taiwan's International Tourist Hotels. Asian Journal of Management and Humanity Sciences 1(3), 434-452.

Yukl, G. (2003). Leadership in organizations (4th ed.). Englewood Cliffs, NJ: Prentice-Hall. 